\title{
Study of the efficiency of energy use of willow chips and torrefied hydrolytic lignin pellets
}

\author{
Viktor Lyubov ${ }^{1}$, Anatoly Popov ${ }^{1,}{ }^{*}$, Evgeniya Popova ${ }^{1}$, Sergey Tretyakov ${ }^{2}$, Andrey \\ Paramonov $^{2}$, and Sergey Koptev ${ }^{2}$ \\ ${ }^{1}$ Northern (Arctic) Federal University named after M.V. Lomonosov, Dept. of Power and Heat \\ Engineering, 163002 Arkhangelsk, Severnaya Dvina emb., 17, Russia \\ ${ }^{2}$ Northern (Arctic) Federal University named after M.V. Lomonosov, Dept. of Forestry and Forest \\ Management, 163002 Arkhangelsk, Severnaya Dvina emb., 17, Russia
}

\begin{abstract}
The lack of raw materials to provide power plants with biofuel requires the search for new energy sources. In the European North of Russia, it is recommended to grow plantings of the willow (Salix L.) in the form of trees or tree-like shrubs, while ensuring a short interval between fellings. The studies show that the artificial cultivation of willow plantations on postagrogenic lands is economically more expedient than the exploitation of natural willow forests. This study examines the energy efficiency of willow wood, which is necessary when planning its use for the production of biofuel (wood chips or fuel pellets) and pellets obtained from torrefied hydrolytic lignin. A comprehensive study of the energy efficiency of willow chips, willow chips with bark, hydrolytic lignin pellets during the operation of the "Firematic 60" hot water boiler was carried out. The elemental composition of the fuels and the resulting ash was studied using an EDX-8000 X-ray fluorescence spectrometer and a Euro EA-3000 analyzer. The components of the heat balance and emission of harmful substances were determined. The emissions of particulate matter and the content of soot particles were studied.
\end{abstract}

\section{Introduction}

In many countries, plantation trees are being grown for reforestation and natural forests conservation. For this reason, the terms of obtaining ripewood are significantly reduced without harming nature. In Sweden, the USA and Canada, plantations produce up to 10-15 tons of willow wood with a relative moisture of $10 \%$ from 1 hectare per year with a rotation of 4 years [1]. The shortest period of obtaining ripe timber for the European North of Russia is noted for the willow (Salix L) tree. The willow grows from the tundra forests to the tropics. Natural ripeness occurs at the age of 25 years, quantitative ripeness - 5-7 years, interval between fellings - from 5 to 15 years, depending on the intended purpose of the grown plantations. The wood is characterized by low density, softness, low resistance to rot damage [2]. The possibility of widespread use of willow wood for board, pulp and paper production, as well as a raw material for biofuels, makes plantation cultivation of willow

* Corresponding author: a.n.popov@narfu.ru 
promising. In this regard, it becomes necessary to study the efficiency of energy use of willow wood. The development of clean energy production requires a large amount of economically available wood raw materials [3]. Plantation cultivation makes it possible to obtain cheaper fuel for energy than the use of natural forests of willow [4]. There were no experiments on plantation cultivation of willow in the European North-East of Russia.

On the territory of the Arkhangelsk Region, large areas are occupied by lands with excessive moisture. Farming is impractical on such lands, but willows grow most productively here. In Russia, there are more than 130 species of willow, among which about 30 species grow in the Arkhangelsk region [2, 5, 6].

According to the data of the state forestry cadastre in the Arkhangelsk region, tree willow grows on an area of 5.3 thousand hectares [7]. The willow shrub form is also widespread, but in most cases the sites are not taxed as plantations and are classified as sands, wetlands, protective road strips, etc.

Willows occupy an important place in the dendroflora of the middle zone of the European part of Russia in terms of species diversity and high intrapopulation variation [8$11]$.

Currently, in the European North of Russia, willows are represented as a new direction in the practice of forestry and in the chemical industry. Therefore, the cultivation and use of willow in the industry with a short rotational cycle [12] opens up entrepreneurial opportunities in the conditions of the Arkhangelsk region. World and domestic experience show that this direction of forestry is promising [4, 12, 13, 14].

Research work was carried out in the Educational and Scientific Center for Power Engineering Innovations of the Higher School of Power Engineering, Oil and Gas connected to the district heating system. Reserve source of heat supply to the building is the Firematic 60 boiler by the Austrian company Herz Energietechnik GmbH which is also used in the implementation of laboratory works and research. The boiler is designed for burning wood pellets and chips [15]. According to the manufacturer, the rated boiler power $(60 \mathrm{~kW})$ is ensured when operating on biofuels with a related moisture of $\mathrm{Wtr}<25 \%$. The design and principle of operation of the boiler are considered in the paper [16].

Acid hydrolysis of wood and agricultural waste was widely used in the Soviet Union to produce ethanol, fodder yeast, sugars and their derivatives [17-19]. In the technological cycle of hydrolysis production, lignin is formed - a large-tonnage by-product. Despite the fact that utilization-energy boilers were installed at many enterprises of the microbiological industry, they could not fully ensure the combustion of lignin, therefore, a significant part of it was taken out to dumps [17-19]. These dumps cause significant harm to the environment due to the alienation of large areas and exposure to acidic components. Pelletizing is a promising direction for obtaining refined biofuel from lignin hydrolyzed. The combination of this process with the preliminary torrefaction of the feedstock makes it possible to obtain refined biofuel with increased energy density and consumer qualities.

One of the objectives of this work was to determine the combustion efficiency of granulated fuel obtained from torrefied hydrolytic lignin.

\section{Materials and Methods}

A comprehensive study of the efficiency of using willow wood and torrefied hydrolytic lignin pellets was carried out in three stages. During the first stage, balance tests were carried out when burning willow chips (Table 1, tests No. 1, 2). At the second stage, the boiler worked on willow chips with bark (Table 1, tests No. 3, 4). During the third stage, pellets obtained from torrefied hydrolytic lignin at Bionet biofuel production company were burned in the boiler furnace (Table 1, tests No. 5,6). The grain size distribution of burned fuels is shown in Figure 1. The analysis of fuels was carried out with equipment of thermal 
analysis lab and IKA C2000 basic Version 2 calorimeter and LOIP-FT-216-25 cryothermostat. The elemental composition of the burned fuels and residues was studied using an EDX-8000 X-ray fluorescence spectrometer and a Euro EA-3000 analyzer. Study of the grain size distribution of fuels and combustion residues was carried out with AS200 and Microtrac S3500 sieve shakers. The determination of velocity fields and flue gas flows was performed with a Pitot tube and micromanometer of Testo- 435 precision instrument. In order to determine the particulate matter concentrations at the flue gas after the boiler was used external filtration method which is applied via an OP-442 TC impactor, a dust sampling probe, a filter holder, etc. A Testo 350XL gas analyzer was used to determine content of combustion products. Fuel consumption was determined by the inverse heat balance equation. Processing of experimental data was carried out using a multi-module software and methodological complex [17].

\section{Results}

The main results are presented in Table 1. For each type of fuel only two tests were carried out which show the energy and environmental performance of the boiler. Thermal analysis of fuels showed that dry and ash free calorific value $\left(Q^{d a f}{ }_{i}=18.495 \mathrm{MJ} / \mathrm{kg}\right)$ of willow chips with bark is higher than of willow chips $\left(Q^{\text {daf }}{ }_{i}=17.657 \mathrm{MJ} / \mathrm{kg}\right)$. Considering that the moisture and ash content of willow chips with bark were higher (Table 1) than willow chips, the low calorific value as received in the latter had a higher value. The volatiles content is higher in willow chips (Table 1). Hydrolytic lignin pellets have a greater low calorific value, since they undergo torrefaction in the process of "soft" pyrolysis. Heat treatment is carried out without air access at a temperature of $\sim 200^{\circ} \mathrm{C}$. As a result of this process, the properties of biomass change and they approach the properties of power plant coal.

Table 1. The main performance of the boiler burning willow chips, willow chips with bark and torrefied hydrolytic lignin pellets

\begin{tabular}{|c|c|c|c|c|c|c|c|}
\hline \multirow{2}{*}{ Value } & \multirow{2}{*}{$\begin{array}{c}\text { Symbol, } \\
\text { dimension }\end{array}$} & \multicolumn{6}{|c|}{ Tests } \\
\hline & & No. 1 & No. 2 & No. 3 & No. 4 & No. 5 & No. 6 \\
\hline Heat capacity & $Q, \mathrm{~kW}$ & 70.2 & 74.7 & 70.7 & 69.9 & 87.2 & 91.4 \\
\hline $\begin{array}{l}\text { Outlet operating } \\
\text { pressure of the water }\end{array}$ & $P_{o . p}, \mathrm{MPa}$ & 2.8 & 2.9 & 3.9 & 3.9 & 3.0 & 3.0 \\
\hline Outlet water temperature & $t_{\text {o.w }},{ }^{\circ} \mathrm{C}$ & 78.0 & 80.0 & 80.0 & 81.0 & 80.0 & 79.0 \\
\hline Moisture of fuel & $W_{t}^{r}, \%$ & \multicolumn{2}{|c|}{10.80} & \multicolumn{2}{|c|}{16.71} & \multicolumn{2}{|c|}{6.27} \\
\hline Ash content of fuel & $A^{r}, \%$ & \multicolumn{2}{|c|}{0.47} & \multicolumn{2}{|c|}{0.80} & \multicolumn{2}{|c|}{2.45} \\
\hline Volatile yield & $V^{d a f}, \%$ & \multicolumn{2}{|c|}{85.80} & \multirow{2}{*}{\multicolumn{2}{|c|}{$\begin{array}{l}83.18 \\
14.83\end{array}$}} & \multicolumn{2}{|c|}{63.85} \\
\hline Low calorific value & $Q^{r} i, \mathrm{MJ} / \mathrm{kg}$ & \multicolumn{2}{|c|}{15.38} & & & \multicolumn{2}{|c|}{21.34} \\
\hline Flue gas temperature & $\vartheta_{f . g},{ }^{\circ} \mathrm{C}$ & 153 & 165 & 148 & 145 & 160 & 157 \\
\hline Excess air in flue gas & $\alpha_{f . g}$ & 1.43 & 1.39 & 1.38 & 1.41 & 1.45 & 1.42 \\
\hline \multicolumn{8}{|l|}{ Heat loss: } \\
\hline flue gas & $q_{2}, \%$ & 7.91 & 8.48 & 7.21 & 7.15 & 6.88 & 6.60 \\
\hline incomplete combustion & $q_{3}, \%$ & 0.02 & 0.03 & 0.01 & 0.02 & 0.00 & 0.00 \\
\hline carbon & $q_{4}, \%$ & 0.21 & 0.21 & 0.40 & 0.40 & 0.47 & 0.47 \\
\hline external & $q_{5}, \%$ & 0.43 & 0.40 & 0.42 & 0.43 & 0.34 & 0.33 \\
\hline $\begin{array}{l}\text { Gross efficiency of the } \\
\text { boiler }\end{array}$ & $\eta_{\text {gross, }} \%$ & 91.42 & 90,87 & 91.92 & 91.98 & 92.25 & 92.55 \\
\hline Total fuel consumption & $B, \mathrm{~kg} / \mathrm{h}$ & 18.0 & 19.0 & 19.0 & 18.0 & 16.0 & 17.0 \\
\hline Emission of $\mathrm{NO}_{x}$ & $\mathrm{NO}_{x}, \mathrm{mg} / \mathrm{MJ}$ & 126.0 & 119.0 & 138.0 & 142.0 & 46.0 & 44.0 \\
\hline Emission of $\mathrm{CO}$ & $\mathrm{CO}, \mathrm{mg} / \mathrm{MJ}$ & 23.0 & 35.0 & 16.0 & 18.0 & 3.0 & 3.0 \\
\hline PM emission & $\mathrm{PM}, \mathrm{mg} / \mathrm{MJ}$ & - & - & 18.0 & - & 9.59 & 9.34 \\
\hline
\end{tabular}


The results of elemental analysis showed that the carbon content in the willow bark is higher and the oxygen content is lower than in willow wood (Table 2), which determines its higher low calorific value on dry and ash free fuel basis.

Woody biomass contains very small amounts of heavy metals; however, during its combustion, the concentrations of heavy metals in the resulting ash increase, while the degree of concentration for different elements varies greatly.

After an automatic start-up of the boiler the period it takes to reach the rated load does not exceed 20 minutes. After 33-38 minutes an automated control system provides inlet boiler water temperature close to the optimum value $\left(60^{\circ} \mathrm{C}\right)$.

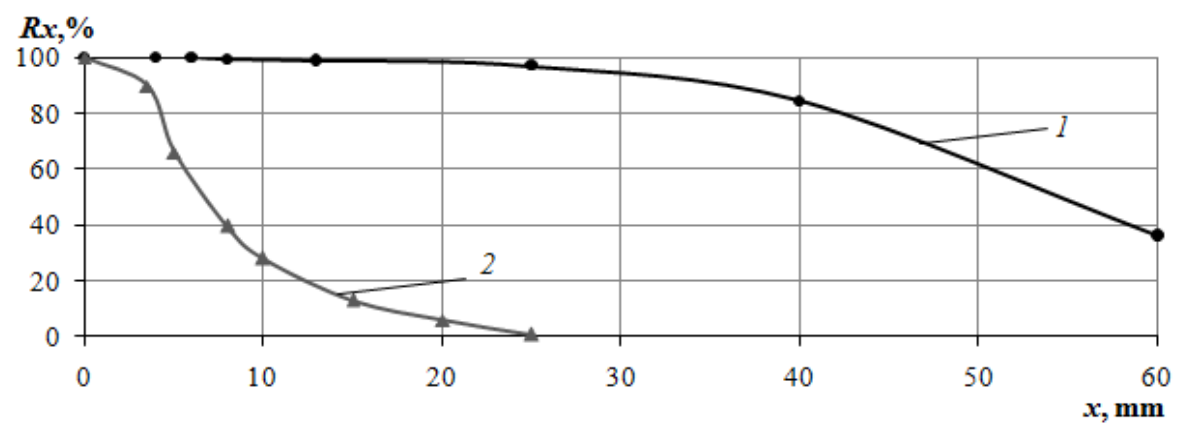

Fig. 1. Grain size distribution of the fuels: 1 - willow chips with bark; 2 - hydrolytic lignin pellets.

The grain size distribution of the focal residues taken from the ashpits of the furnace and the heat exchanger during the combustion of willow chips and hydrolytic lignin pellets is shown in Fig. 2.

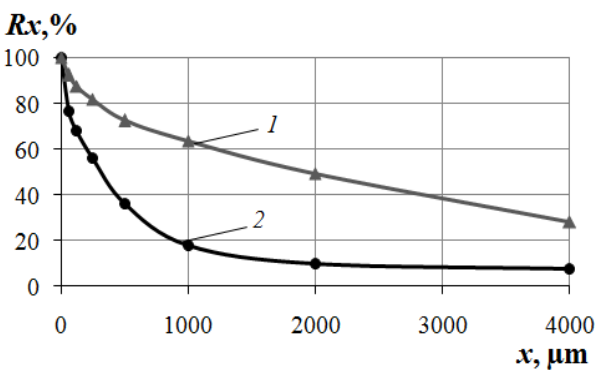

a

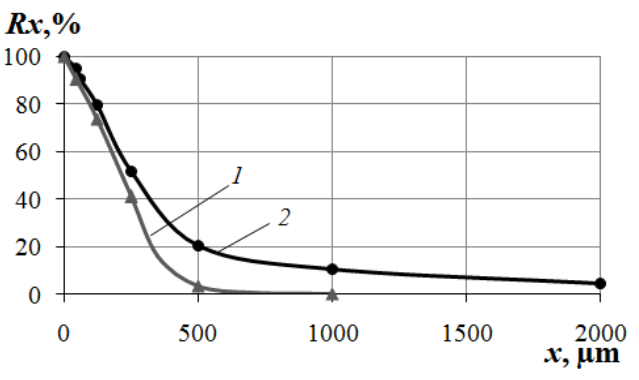

$\mathrm{b}$

Fig. 2. Grain size distribution of focal residues formed during combustion: 1 - hydrolytic lignin pellets; 2 - willow chips taken: $a$ - from the ash pit of the furnace; $b$ - from under the heat exchanger.

Particulate matter at a $180^{\circ}$ turn of the combustion products after the first pass in the fire tubes is separated into an ash box, from where it is removed by a screw into an ash bin.

Fly ash from combustion of willow chips, taken from under the heat exchanger, has a high degree of polydispersity of grain size distribution $(\mathrm{n}=1.114)$ and a rather coarse dispersed composition $\left(\mathrm{b}=1.024 \cdot 10^{-3}\right)$. At the same time, it is dominated by particles with a size from 63 to $500 \mu \mathrm{m}$, the mass fraction of which is $69.97 \%$. Fractional analysis showed that the largest number of combustible components is contained in particles with a size of $500 \mu \mathrm{m}$ or more (Figure 3a). An analysis of the experimental data, taking into account the mass content of different fractions, showed that the decisive share in carbon loss is exerted by the underburning of combustible components in particles with a size of $125<\mathrm{x}<1000$ $\mu \mathrm{m}$ (Figure 3b). 


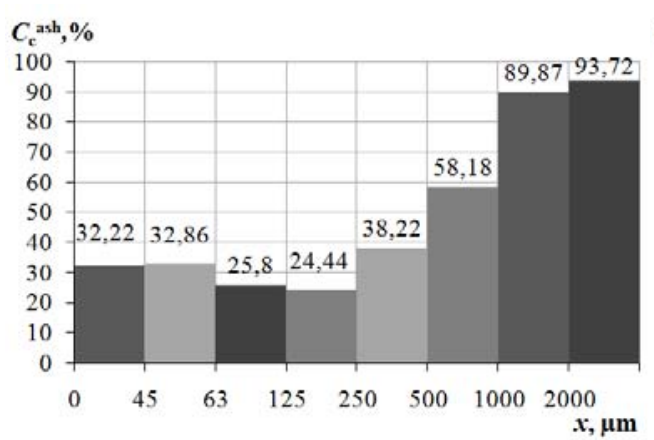

a

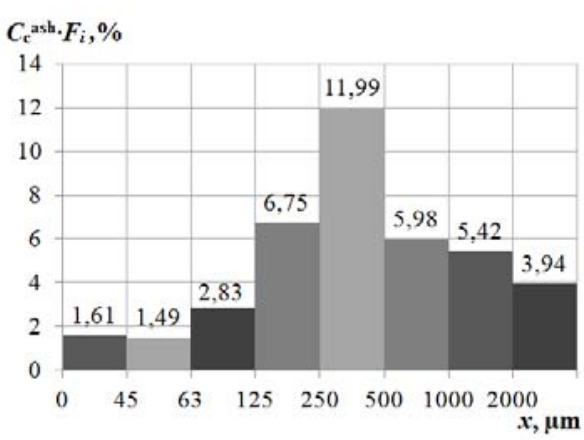

$\mathrm{b}$

Fig. 3. Content of combustible components in fly ash separated into the heat exchanger when burning willow chips: $\mathrm{a}$ - fractional distribution; $\mathrm{b}$ - concentration of combustible components taking into account weight percentage of different fractions.

Table 2. Elemental composition of wood and bark of willow and their ashes on a dry weight, $\%$.

\begin{tabular}{cccc}
\hline Element & \multicolumn{3}{c}{ Test fuels and residues } \\
\cline { 2 - 4 } & Willow wood & Willow bark & Willow ash \\
\hline Barium & - & 0.001 & 0.085 \\
Strontium & - & 0.003 & 0.143 \\
Zinc & 0.003 & 0.028 & 0.198 \\
Cuprum & 0.004 & 0.003 & 0.039 \\
Ferrum & 0.031 & 0.013 & 1.35 \\
Manganese & 0.002 & 0.016 & 0.288 \\
Titanim & 0.001 & 0.001 & 0.083 \\
Calcium & 0.126 & 1.05 & 30.3 \\
Potassium & 0.061 & 0.315 & 11.6 \\
Sulfur & 0.026 & 0.067 & 1.26 \\
Phosphorus & 0.041 & 0.097 & 4.76 \\
Silicon & 0.009 & 0.017 & 4.37 \\
Aluminium & 0.011 & 0.027 & 0.684 \\
Magnesium & 0.047 & 0.126 & 6.43 \\
Rubidium & - & - & 0.020 \\
Plumbum & 0.001 & 0.001 & 0.001 \\
Carbon & 47.66 & 48.13 & 0.743 \\
Nitrogen & 0.39 & 0.37 & - \\
Hydrogen & 8.05 & 8.00 & - \\
Oxygen & 43.6 & 41.7 & 37.7 \\
\hline
\end{tabular}

Ash and slag formed during the combustion of willow chips taken from under the combustion chamber have an even more polydispersity grain size distribution $(n=0.595)$ than fly ash, while the focal residues are dominated by particles ranging in size from 125 to $1000 \mu \mathrm{m}$, the mass fraction of which is $50.53 \%$. The proportion of particles less than $63 \mu \mathrm{m}$ in size is also high, the weight content of which was $23.14 \%$.

\section{Discussion}

The analysis of thermal conditions showed that heat loss with flue gas is $\mathrm{q}_{2}=6.6-8.48 \%$, but it rises when load and inlet boiler water temperature increases.

A stage fuel combustion scheme and efficient mixing of secondary air with combustible components while keeping the excess air coefficient in furnace withing the range 1.38-1.45 allowed to reach low values of heat loss due to incomplete fuel combustion (no more than 
$0.03 \%)$. Values of carbon oxide concentrations corrected to excess air coefficient of 1.4 are 8.0-77.0 mg/ $\mathrm{Nm}^{3}$.

Carbon loss when boiler operates on willow chips was very low $\mathrm{q}_{4}=0.24 \%$ due to the uniformity of the grain size distribution and low ash content of the fuel. The content of combustible components in fly ash from the furnace, as well as in the slag during were $C^{c}$ ash $=39.91 \%$ and $C^{c}$ slag $=8.81 \%$. Willow chips with bark have a higher ash content and a less uniform grain size distribution. This caused an increase in carbon loss, while the content of combustible components in fly ash and slag amounted to $C^{c}{ }_{a s h}=43.10 \%, C^{c}$ slag $=8.65 \%$. When the boiler operates on lignin pellets, the ash content of which is much higher than that of willow chips, heat losses with carbon loss increased to $0.47 \%$, despite a fairly uniform particle size distribution and greater calorific value.

Experimental studies have shown that the design of the boiler allows for efficient burning of willow chips. When operating on hydrolytic lignin pellets, the boiler is capable of efficient operation with a load higher than the nominal one.

To determine the external heat loss, an amended approach was used, based on a combination of relative and calorimetric methods supplemented with thermal imaging [15]. External heat loss for rated load $(60 \mathrm{KW})$ of the boiler does not exceed $0.5 \%$ that is significantly lower in comparison with Russian standards [20]. Low values of this loss are explained by moderate overall dimensions of the boiler and high quality of lining and thermoinsulation materials.

Losses due to temperature of bottom ash when the boiler was operating on willow chips did not exceed $\mathrm{q}_{6}=0.01 \%$, when burning willow chips with bark $0.02 \%$, and when operating on hydrolytic lignin pellets $0.06 \%$.

A promising direction for obtaining refined biofuel is the production of torrefied pellets. Thus, the organization of the production of torrefied granules from lignin hydrolyzed made it possible to obtain high-quality fuel from biomass, which had been in dumps for 40-60 years. Transition from willow chips to burning the hydrolytic lignin pellets led to increase of boiler efficiency to $92.25-92.55 \%$; despite the higher ash content of the latter $(5.56$ times). This is due to the higher thermal characteristics of torrefied pellets. In addition, with the burning of the pellets, minimal emissions of nitrogen oxides and carbon monoxide were achieved.

Low emission of $\mathrm{NO}_{\mathrm{x}}$ for each fuel is explained by moderate level of maximum temperatures and excess air in combustion chamber as well as two-stage combustion scheme. Sulfur dioxide in the combustion products during the burning of biofuels was absent in all modes of operation of the boiler.

Stage combustion scheme and intensive mixing of secondary air with combustible components of fuel allow to provide highly efficient operation of the boiler in the condition of low oxygen concentration of 4.0-6.0\%. As oxygen concentration increases by more than $6 \%$ the emission of harmful substances to the atmosphere rises too. To that end the threshold value of oxygen concentration should be reduced to $4 \%$ in the automated control system.

The results of research of soot particles emission with the use of external filtration method [22] under isokinetic conditions of gas extraction [21] have shown that soot emission factor when burning willow chips with bark was $7.76 \mathrm{~g} / \mathrm{GJ}$. The average PM2.5 emission factor (with a conversion coefficient of 0.14 [23]) was $1.086 \mathrm{~g} / \mathrm{GJ}$. When the boiler operates on hydrolytic lignin pellets average soot emission factor was $2.467 \mathrm{~g} / \mathrm{GJ}$, and PM2.5 emission factor - $0.345 \mathrm{~g} / \mathrm{GJ}$. As a comparison, the average soot emission factor for Arimax Bio Energy hot water boilers with a nominal power of 1.5 MW, operating on wood pellets and equipped with inertial ash collectors, was $5.75 \mathrm{~g} / \mathrm{GJ}$, and PM2.5 emission factor $-0.805 \mathrm{~g} / \mathrm{GJ}$. 


\section{Conclusion}

Willow is a promising raw material for use as a biofuel due to the short period of obtaining ripe wood during plantation cultivation. Laboratory analysis showed that willow wood with bark has a greater dry and ash free calorific value than wood without bark. The volatile content is higher for willow chips. Burning willow chips is quite energy efficient. The use of torrefied hydrolytic lignin pellets as biofuel is a promising direction for areas where hydrolysis production has been operating for a long time.

The Firematic 60 hot water boiler provides high technical and economic performance and minimal emissions of harmful substances to the environment when burning willow chips and hydrolytic lignin pellets. When working on hydrolytic lignin pellets, it is possible to ensure efficient operation with a load higher than the nominal one.

\section{References}

1. S.P. Kundas, S.S. Poznyak, O.I. Rodzkin, V.V. Sanikovich, E. Lengfelder, Energy use of woody biomass: scientific report (Int. Sakharov Env. Institute, Minsk, 2008)

2. A.K. Skvorcov, Willow of USSR (Nauka, Moscow, 1968)

3. A.O. Ilyin, The project of transferring boiler houses of the Arkhangelsk region to biofuel [electronic source], (Newsletter, Energosvet, 2009)

4. O.I. Rodzkin, O.A. Shkutnik, Ekologicheskii Vestnik, 3(33), 62-68 (2015)

5. N.A. Demidova, T.M. Durkina, Belgorod St. Uni. Sci. B. Natural Sciences, 21(140), 21-29 (2012)

6. T.E. Teplyakova, Biosfera, 4(1), 27-68 (2012)

7. Forest plan of Arkhangelsk region (Governor’s Decree № 116-y, 2018)

8. G.I. Anciferov, Willow (Lesnaya promyshlennost', Moscow, 1984)

9. A.A. Afonin, Identification of wild willows (Salix) of southwest Russia (BrGU, Bryansk, 2003)

10. A.A. Afonin, Forestry J., 2(3) (2003)

11. A.I. Gorbec, Productivity of natural cenoses and prospects for plantation cultivation of willow in the central forest-steppe, thesis (Voronezh, 2019)

12. A.I. Gorbec, Forestry Eng. J. 5(4) (2015)

13. O.I. Rodzkin, S. Orlovićh, B. Krstić, A. Pilipović, Vestnik IrGSHA, 58, 69-77 (2013)

14. O.I. Rodzkin, N.N. Vaicekhovich, O.A. Shkutnik, S. Orlovićh, B. Krstić, B. Klašnja, A. Pilipović, B. Kovačević, Vestnik IrGSHA 56, 46-54 (2013)

15. V.K. Lyubov, P.V. Malygin, A.N. Popov, E.I. Popova, Therm. Eng. 62(8), 572-576 (2015)

16. V.K. Lyubov, A.N. Popov, E.I. Popova, Ecol. and Ind. of Russia 23(3), 20-25 (2019)

17. V.K. Lyubov, S.V. Lyubova, Increasing of biofuels usage efficiency (Arkhangelsk, NArFU, 2017)

18. M.L. Rabinovich, O. Fedoryak, G. Dobele, A. Andersone, B. Gawdzik, M.E. Lindström, O. Sevastyanova, Renew. and Sust. En. Reviews 57, 1008-1024 (2016)

19. M.L. Rabinovich, Cell. Chem. and Tech. 44(4-6), 173-186 (2010)

20. Thermal design of boilers. Standard method (Saint-Petersburg, NPO CKTI, 1998)

21. Collection of Methods of determination of harmful substances concentrations in industrial emissions (Leningrad, Gidrometeoizdat, 1987) 
22. Method of Soot Mass Concentration Measurements in Industrial Emissions and in the Air of Operational Areas (OAO NII «TEHUGLEROD», 2005)

23. H. Borchsenius, D. Borgnes, Black carbon emissions from the district heating sector in the Barents region (NORSK ENERGI, 2013) 